твенный аграрный университет имени Н.И. Вавилова. Россия.

Беляева Екатерина Анатольевна, магистрант, Саратовский государственный аграрный университет имени Н.И. Вавилова. Россия.
410056, г. Саратов, ул. Советская, 60. Тел.: (8452) 74-96-29.

Ключевые слова: теплица; температура; микроклимат; солнечная радиация; устройство.

\title{
NEW DESIGN OF THE DEVICE TO PREVENT OVERHEATING THE GREENHOUSE FROM SOLAR RADIATION IN THE WARM PERIOD
}

Abdrazakov Fyarid Kinzhevich, Doctor of Technical Sciences, Professor, Head of the chair "Construction, Heat and Gas Supply and Energy Supply", Saratov State Agrarian University named after N.I. Vavilov. Russia.

Khalmetov Azat Ahmetovich, Candidate of Technical Sciences, Associate Professor of the chair "Construction, Heat and Gas Supply and Energy Supply”, Saratov State Agrarian University named after N.I. Vavilov. Russia.

Belyaeva Ekaterina Anatol'evna, Magistrandt, Saratov State Agrarian University named after N.I. Vavilov. Russia.
Keywords: greenhouse; temperature; microclimate; solar radiation; device.

The article describes the optimal temperature regimes for vegetable crops and discusses the existing methods of protecting the greenhouse from solar radiation during the warm period. Based on the analysis of existing devices, a new design of the greenhouse screening device, which allows reducing the temperature by $5 . . .8{ }^{\circ} \mathrm{C}$ is proposed.

\section{ПОТОЧНЫЙ СПОСОБ ОБЕЗЗАРАЖИВАНИЯ ЭЛЕКТРИЧЕСКИМ ПОЛЕМ И ПЕРЕРАБОТКИ ПОМЕТА В ОРГАНИЧЕСКОЕ УДОБРЕНИЕ}

\author{
ГУРЬЯнОВ Дмитрий Валерьевич, Мичуринский государственный аграрный университет \\ ХМЫРОВ Виктор Дмитриевич, Мичринский государственный аграрный университет \\ ГУРьЯнОВА Юлия Викторовна, Мичуринский государственный аграрный университет
}

Рассматривается поточный способ обеззараживания и переработки помета в органическое удобрение путем создания электрического поля в органической массе. В результате обеззараживания помета данным способом полностью уничтожаются микробиота, грибные колонии, болезнетворные бактерии и гельминты. Проведенный микроскопический анализ качественного состава микробиоты показал, что равномерное распределение воздушного потока в аэрационной массе помета подстилочного навоза позволяет повышать температуру в биореакторе и приводит к интенсивному разложению органической массы. Выявлено, что представленный способ обеззараживания и переработки куриного помета является высокоэффективным и экологически безопасным.

Введение. Важная роль в повышении плодородия, улучшении структуры, снижении плотности почвы, повышении урожайности и получении высококачественной сельскохозяйственной продукции отводится органическим удобрениям. Они способствуют накоплению в почве гумуса и элементов питания для растений. Сельскохозяйственные отходы, навоз всех видов, солома зерновых и крупяных культур, тор $\phi$, озерный ил, ботва сахарной свеклы являются компонентами приготовления органических удобрений.

Особое значение в приготовлении органических отходов имеет помет птицы. В свежем виде помет птицы при внесении в почву приносит вред растениям, которые погибают при больших дозах. Поэтому помет, полученный на птицефабриках и птицефермах при клеточном и групповом содержании на глубокой подстилке, необходимо перерабатывать в аэрационных цехах и биореакторах в органические удобрения.

В данном исследовании рассматривается поточная технология переработки помета в орга- ническое удобрение. На площадке помет и наполнители измельчаются, перемешиваются и укладываются в бурт на трое суток, затем скребковым транспортером органическая масса загружается в биореактор, где выравнивается и перемещается сверху вниз к выгрузному транспортеру. За счет гравитационных сил масса проходит через электроды, где обеззараживается, а поступающий через воздуховодные отверстия воздух способствует нагреву органической массы до $60 . .65^{\circ} \mathrm{C}$, что позволяет ускорить бурное развитие термофильных микроорганизмов. В процессе биоферментации и обеззараживания физическими методами происходит гибель патогенной микрофлоры, грибов, болезнетворных бактерий, гельминтов и семян сорных растений. Полученное органическое удобрение - экологически чистое и высокого качества. Химический анализ показывает, что содержание азота, фосфора и калия увеличивается по сравнению с исходной органической массой.

Птицеводство - важная отрасль сельскохозяйственного производства, которая дает продукты 
питания для человека (мясо птицы, яйцо, потрошки) и сырье для перерабатывающей промышленности (пух, перо). При производстве продукции птицеводства основным загрязняющим фактором является помет. На птицефабриках с поголовьем 400 тыс. кур суточный выход помета составляет 100 т. При содержании кур на глубокой подстилке в помещении $120 \times 21$ м - 300 т за стойловый период. Исходя из этого, точный объем помета необходимо утилизировать и перерабатывать в органическое удобрение. Полученное органическое удобрение после аэрации в цехах и биореакторах-обеззараживателях необходимо вносить в почву с целью улучшения структуры почвы, восстановления естественного плодородия и повышения урожайности почв, а также повышения содержания гумуса без нанесения экологического ущерба окружающей среде.

Цель исследования - обеззараживание и аэрация куриного помета при приготовлении органических удобрений поточным способом.

Методика исследований. Поточный способ переработки помета в органическое удобрение представлен на рис. 1 .

Самоходный смеситель 1 передвигается по площадке, перемешивая помет с углеводородами (измельченная солома, торф), и укладывает в бурт. Через 3-5 суток органическая масса из бурта 2 загружается в завальную яму скребкового транспортеpa 3, который в свою очередь загружает органическую смесь в аэрационный биореактор-обеззараживатель [2]. Конструкция аэрационного биореакто-
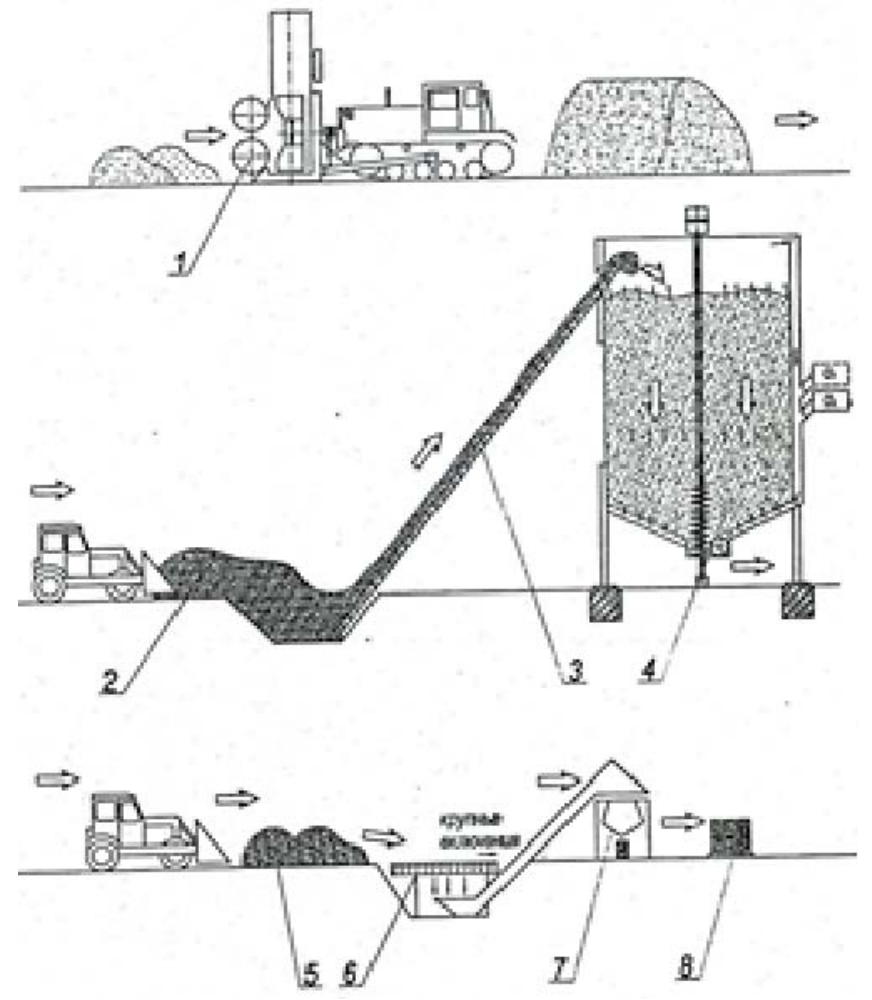

2019 Рис. 1. Схема поточного способа переработки помета в органическое удобрение:

1 - самоходный смеситель; 2 - бурт органической массы; 3 - скребковый транспортер; 4 - биореактор; 5 - бурт дозревания;

6 - сепаратор; 7 - упаковочное устройство; 8 - готовое органическое удобрение ра-обеззараживателя представляет собой емкость круглого сечения, в нижней части которого установлен выгрузной цепочно-планчатый транспортер. Внутри по периметру установлены воздуховодные трубы с отверстиями и электроды. Органическая масса в течение 5 суток проходит через электроды, которые создают электрическое поле для гигиенизации полученных удобрений. По воздуховодным трубам в органическую массу подается воздух для создания в биореакторе благоприятных условий для развития мезо- и термофильной микрофлоры, которая приводит к интенсивному разложению органической массы и сопровождается резким повышением температуры до $65 . . .70{ }^{\circ} \mathrm{C}$ (рис. 2).

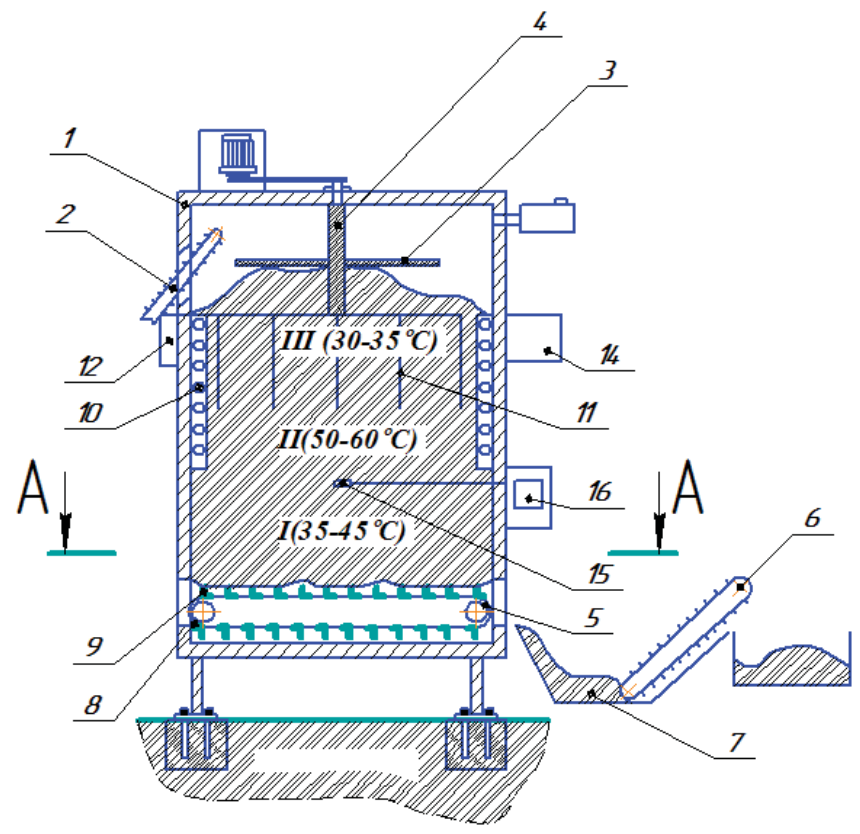

Рис. 2. Аэрационный биореактор-обеззараживатель помета

Исследования распределения воздушного потока с одинаковыми диаметрами воздуховодных отверстий проводили следующим образом: поочередно у каждого воздуховодного отверстия на расстоянии 5 см устанавливали анемометр MC-13,5 и снимали показания. Полученные результаты представлены в графической форме.

На рис. 2 показана конструкция аэрационного биореактора-обеззараживателя помета, которая состоит из закрытого теплоизоляционного корпуса 1 , устройства для подачи исходного сырья в виде скребкового транспортера 2, в верхней части которого установлено приспособление для выравнивания исходного материала, выполненное в виде лопастей 3, установленных на валу 4, цепочно-скребкового транспортера для выгрузки готового удобрения 5, погрузочного скребкового транспортера 6, завальной ямы 7, цепи скребкового транспортера 8, скребка 9, воздудоводных труб 10, электродов для создания электрического поля в органической массе 11 , источника питания 12 , электропривода цепочно-скребкового транспортера 13, воздуходувки 14, датчика температуры органической массы 15, микропроцессорного регулятора температуры 16, воздуховодных отверстий 17. 
Аэрационный биореактор-обеззараживатель работает следующим образом. Помет птицы влажностью 50-55 \% выдерживается в буртах в течение 3-5 суток. Далее помет скребковым транспортером 2 загружается в корпус 1 круглой формы с открытым дном. Равномерность распределения материала по всему объему обеспечивается лопастями 3 , установленными в верхней части корпуса на валу 4 .

Результаты исследований. Эксперименты проводили в зависимости от длины воздуховодной трубы при диаметре воздуховодных отверстий 10 мм (рис. 3).

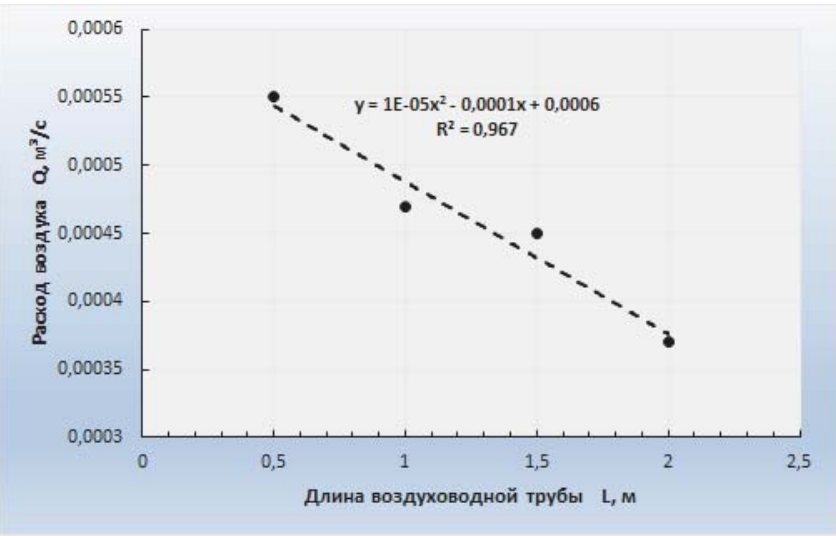

Рис. 3. Зависимость расхода воздуха от длины аэрационной трубы

Графическая зависимость, представленная на рис. 3, показывает резкое снижение расхода воздуха при удалении воздуховодных отверстий от вентилятора с 0,00055 до 0,00037 м³ с. Следовательно, воздух при такой подаче в аэрационной массе распределяется неравномерно и будет наблюдаться недостаточное повышение температуры в отдельных зонах массы аэратора. Для равномерного распределения воздушного потока в аэрационной массе проводили исследования зависимости расхода воздуха через воздуховодные отверстия с диаметром от 10 до 24 мм (рис. 4).

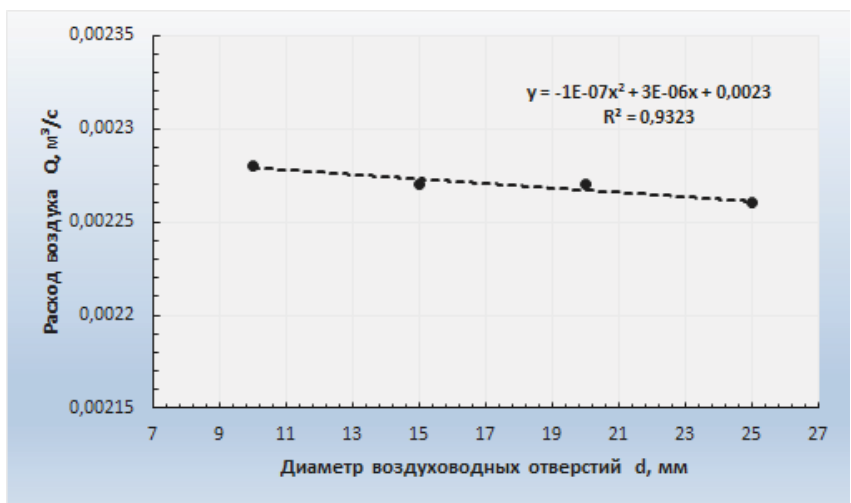

Рис. 4. Зависимость расхода воздуха от диаметра воздуховодных отверстий

Из графика видно, что при увеличении диаметра воздуховодного отверстия с 10 до 24 мм и при удалении от вентилятора на 2 м расход воздуха остается постоянной величиной. Следовательно, воздух в аэрационной массе аэратора распределяется равномерно.
Компостируемый материал медленно перемещается сверху вниз за счет гравитационных сил, через воздуховодные трубы помет насыщается воздухом и создаются благоприятные условия в биореактореобеззараживателе для развития мезо- и термофильной микрофлоры [1,3], что в свою очередь приводит к интенсивному разложению органической массы и повышению температуры до $60 . . .70{ }^{\circ} \mathrm{C}$ (рис. 5), а электроды, установленные внутри биореактора, создают электрическое поле в органической массе и дополнительно уничтожают микробиоту, грибные колонии, болезнетворные бактерии и гельминты.

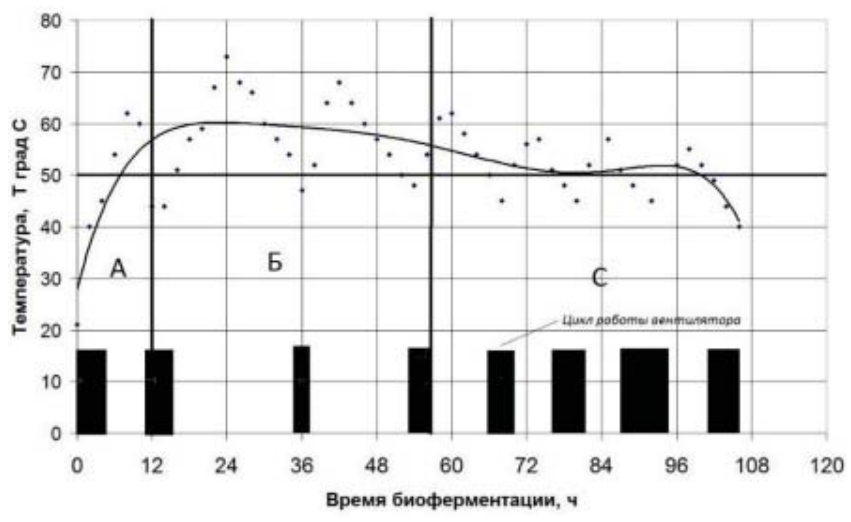

Рис. 5. Зависимость температуры от времени биоферментации органической массы:

А - зона разогрева (мезофильная); В - зона горения (термофильная); С - зона затухания (дозревание органического удобрения)

Полученное органическое удобрение экологически чистое, высокого качества.

Заключение. Полученные результаты исследований свидетельствуют, что равномерное распределение воздушного потока в аэрационной массе помета, подстилочного навоза позволяет повышать температуру в биореакторе и приводит к интенсивному разложению органической массы. После разгрузки биореактора полученное органическое удобрение должно дозревать в буртах в течение 10 суток. Готовые удобрения можно расфасовывать в пакеты, мешки и отправлять потребителям.

Представленный способ обеззараживания и переработки куриного помета является высокоэффективным и экологически безопасным, что подтверждается результатами экспериментов.

\section{СПИСОК ЛИТЕРАТУРЫ}

1. Аэрационный биореактор-обеззараживатель органической массы/ Д.В. Гурьянов [и др.] // Вестник Мичуринского ГАУ. - 2017. - № 2. - С. 109-114.

2. Гурьянов Д.В., Хмыров В.Д., Гурьянова Ю.В. Аэрационный биореактор-обеззараживатель подстилочного навоза непрерывного действия // Аграрный научный журнал. - 2018. - № 5. - С. 45-47.

3. Чернова Е.Н., Стариев А.С. Экспериментальная зависимость содержания остатка экскрементов на транспортерной ленте клетки для содержания телят от угла наклона скребка очищающего к плоскости ленты // Научная мысль. - 2015. - № 3. C. 222-227. 
Гурьянов Дмитрий Валерьевич, канд. техн. наук, доиент кафедры «Агроинженерия, электроэнергетика и информационные технологии», Мичуринский государственный аграрный университет. Россия.

Хмыров Виктор Дмитриевич, $\partial-p$ техн. наук, проф. кафедры «Технологические проиессы и техносферная безопасность», Мичуринский государственный аграрный университет. Россия.
Гурьянова Юлия Викторовна, $\partial-p$ c.- $x$. наук, проф. кафедры «Садоводство», Мичуринский государственный аграрный университет. Россия.

393760, Тамбовская обл., г. Мичуринск, ул. Интернациональная, 101.

Тел.: 89107576887; e-mail: guryanov72@mail.ru.

Ключевые слова: помет птицы; аэрационный биореактор; электрическое поле; электроды; органическое удобрение.

\title{
THE PRODUCTION METHOD OF DISINFECTION OF THE ELECTRIC FIELD AND THE PROCESSING OF MANURE INTO ORGANIC FERTILIZER
}

Guryanov Dmitry Valeryevich, Candidate of Technical Sciences, Associate Professor of the chair "Agroengineering, Electric Power and Information Technology", Michurinsk State Agrarian University. Russia.

Khmyrov Viktor Dmitrievich, Doctor of Technical Sciences, Professor of the chair "Processes and Technosphere Safety", Michurinsk State Agrarian University. Russia.

Guryanova Yuliya Viktorovna, Doctor of Agricultural Sciences, Professor of the chair "Horticulture", Michurinsk State Agrarian University. Russia.

Keywords: poultry manure; aeration bioreactor; electric field; electrodes; organic fertilizer.
The article deals with the flow method of disinfection and processing of manure into organic fertilizer by creating an electric field in the organic mass. As a result of the disinfection of the litter, this method completely destroys the microbiota, fungal colonies, pathogenic bacteria and helminths. A microscopic analysis of the qualitative composition of the microbiota was carried out. The analysis showed that the uniform distribution of air flow in the aeration mass of manure, litter manure can increase the temperature in the bioreactor and lead to intensive decomposition of organic matter. It is revealed that the presented method of disinfection and processing of chicken manure is highly effective and environmentally safe.

\section{РЕЗУЛЬТАТЫ ЭКСПЕРИМЕНТАЛЬНЫХ ИССЛЕДОВАНИЙ} РАБОТЫ ЭЛЕКТРИФИЦИРОВАННЫХ ДОЖДЕВАЛЬНЫХ МАШИН
КРУГОВОГО ДЕЙСТВИЯ НА СКЛОНОВЫХ ЗЕМЛЯХ

\author{
ЖУРАВЛЕВА Лариса Анатольевна, Саратовский государственный аграрный университет \\ имени Н.И. Вавилова
}

СОЛОВЬЕВ Владимир Александрович, Саратовский государственный аграрный университет имени Н.И. Вавилова

КУЗНЕЦОВ Андрей Николаевич, Саратовский государственный аграрный университет имени Н.И. Вавилова

КИРИЧЕНКО Андрей Владимирович, Саратовский государственный аграрный университет имени Н.И. Вавилова

лоньКИН Александр Петрович, Саратовский государственный аграрный университет имени Н.И. Вавилова

Рассматривается влияние конструктивно-технологических параметров дождевальных машин и рельефа местности на равномерность распределения оросительной воды по полю. Приводятся характеристики разработанных и внедренных в производство ФГБОУ ВО СГАУ ИМ. Н.И. Вавилова совместно с ООО «Мелиоративные машины» современных отечественных широкозахватных дождевальных машин «Кубань-ЛК1М» (Каскад) и «КАСКАД», а также результаты экспериментальных исследований работы машин на участках полива со сложным рельефом. Представлены данные изменения давления вдоль водопроводящего трубопровода в зависимости от уклонов местности. Получено распределение слоя дождя под пролетами машин для режимов движения 20 и 40 \%. Рассмотрено влияние рельефа местности и скорости движения машинь на коэффициенты эффективности полива. Представлены результаты испытаний дождевальных машин с учащенной схемой расстановки дождевателей и регуляторами давления. Намечены пути повышения равномерности полива иирокозахватными дождевальными машинами на склоновъх землях.

Введение. Многоопорные широкозахватные дождевальные машины за время своего существования претерпели значительные изменения конструкции, связанные с ходовой частью, приводом, ферменной системой, дождеобразующими устройствами. Была усовершенствованна автоматическая система управления.
Однако имеется определенное отставание в разработке технологических рекомендаций по режимам эксплуатации широкозахватной дождевальной техники в зависимости от конструктивных особенностей машин, нет явной взаимосвязи того и другого.

Существенное влияние на равномерность распределения оросительной воды по полю оказыва- 